\title{
Performance evaluation of bullock drawn sprayers for soybean crop
}

\section{R. GUPTA, S.P.S. SOMVANSHI, VENKATA SATISH KUCHI AND H.P. SINGH}

Received : 29.06.2017; Revised : 18.08.2017; Accepted : 03.09.2017

See end of the Paper for authors' affiliation

Correspondence to :

\section{S.P.S. SOMVANSHI}

Krishi Vigyan Kendra (RVSKVV), MANDSAUR (M.P.)

INDIA

Email : surya.somvanshi@ gmail.com
ABSTRACT : The present study was undertaken to evaluate performance of bullock drawn traction sprayer in soybean crop. Malvi breed bullocks were selected for carting operation research work under front line demonstration (FLD) during 2011-12, 2012-13 and 2013-14, at village Surkheda, Badwan and Mohammadpura of Mandsaur (M.P.) The bullock drawn traction sprayer is capable to cover 6 rows at a stretch with an average field capacity of $0.75 \mathrm{ha} / \mathrm{h}$. The average quantity of chemical solution sprayed per hectare was found to be 394.42 1/ha. An operating pressure was 3.8 $\mathrm{kg} / \mathrm{cm}^{2}$. The average travel speed of unit was $2.20 \mathrm{kmph}$. Field efficiency was found 74.2 per cent and labour requirement $2.66 \mathrm{man}-\mathrm{hr} / \mathrm{ha}$. There was a significant $(\mathrm{P}<0.05)$ increase in all the three physiological parameters (respiration rate, pulse rate and body temperature) as compared to their pre-work values.

- KEY WORDS : Physiological response, Bullock drawn sprayer, Discharge rate, Field capacity

- HOW TO CITE THIS PAPER : Gupta, R., Somvanshi, S.P.S., Kuchi, Venkata Satish and Singh, H.P. (2017). Performance evaluation of bullock drawn sprayers for soybean crop. Internat. J. Agric. Engg., 10(2) : 477-480, DOI: 10.15740/HAS/IJAE/10.2/477-480. 